\title{
Quality and Microbial Changes of Fresh-cut Mango Cubes Held in Controlled Atmosphere
}

\author{
Nithiya Rattanapanone ${ }^{1}$, Yuen Lee ${ }^{2}$, Tianxia $\mathrm{Wu}^{3}$, and \\ Alley E. Watada ${ }^{4}$ \\ Horticultural Crops Quality Laboratory, Beltsville Agricultural Research \\ Center, Agricultural Research Service, U.S. Department of Agriculture, \\ Beltsville, MD 20705
}

Additional index words. respiration, bacteria, yeast, shear, color, Mangifera indica

\begin{abstract}
The marketable period of fresh-cut 'Tommy Atkins' and 'Kent' mango cubes was 3 to 5 days at $10^{\circ} \mathrm{C}$ and 5 to 8 days at $5{ }^{\circ} \mathrm{C}$. The marketable period was extended by 1 to 2 days when cubes were held in a $4 \mathrm{kPaO}_{2}+10 \mathrm{kPa} \mathrm{CO}$ or $2 \mathrm{kPa} \mathrm{O}_{2}+10 \mathrm{kPa} \mathrm{CO}_{2}$ (balance $\mathrm{N}_{2}$ ) atmospheres, depending on cultivar and temperature. Variations in texture (shear force), $\mathrm{pH}$, and soluble solids were greater among cubes from different mango lots than among cubes held at different temperatures or atmospheres. Yeast count increased more with time than did the total mesophilic aerobic count, and the increase was less under controlled atmosphere (CA) than in air at $10^{\circ} \mathrm{C}$. The $\mathrm{CA}$ was beneficial in maintaining quality of the cubes; however, low temperature was more effective than $\mathrm{CA}$.
\end{abstract}

Mangoes are delicious, but require peeling, removal of flesh from the seed, and slicing before consumption. Thus, the fruit might have greater appeal if they were peeled and sliced for immediate consumption. Very little is known about the potential shelf life, quality changes, or microbial population of fresh-cut mangoes.

Whole 'Irwin' and 'Tommy Atkins' mango fruit can be stored for 3 weeks at 10 ${ }^{\circ} \mathrm{C}$, whereas some cultivars, such as 'Haden' and 'Keitt', develop chilling injury symptoms at this temperature (Hardenburg et al., 1986). Controlled atmosphere (CA) storage can be used to extend the shelf life, but the extension varies with temperature, atmosphere, and cultivar. 'Alfonso' mangoes can be kept satisfactorily for $35 \mathrm{~d}$ in $7.5 \mathrm{kPa} \mathrm{CO}$ at 8.3 to $10^{\circ} \mathrm{C}$ and 'Raspuri' for $49 \mathrm{~d}$ in 7.5 $\mathrm{kPaCO}_{2}$ at $7.2^{\circ} \mathrm{C}$ (Kapur et al., 1962). 'Haden' mangoes can be successfully stored for $30 \mathrm{~d}$ and 'Carlota', 'Jasmin', and 'Sao Quirino' for

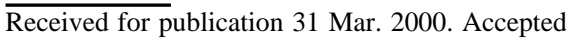
for publication 20 Nov. 2000. We thank Willard Douglas for excellent technical assistance. Use of company or product name by the U.S. Dept. of Agriculture does not imply approval or recommendation of the product to the exclusion of others which also may be suitable. The cost of publishing this paper was defrayed in part by the payment of page charges. Under postal regulation, this paper therefore must be hereby marked advertisement solely to indicate this fact.

${ }^{1}$ Current address: Dept. of Food Science and Technology, Faculty of Agro-industry, Chiang Mai Univ., Doi Come Campus, Chiang Mai, 50200 Thailand. ${ }^{2}$ Current address: Dept. of Biological and Environmental Sciences, Univ. of District of Columbia, Washington, D.C.

${ }^{3}$ Current address: Agronomy Dept., Nanjing Agricultural Univ., Peoples Republic of China.

${ }^{4}$ To whom reprint requests should be addressed. E-mail address: yoal@earthlink.net
}

$35 \mathrm{~d}$ in an atmosphere of $6 \mathrm{kPa} \mathrm{O}_{2}$ plus $10 \mathrm{kPa}$ $\mathrm{CO}_{2}$ at $8^{\circ} \mathrm{C}$ (Bleinroth et al., 1977). Maekawa (1990) maintained 'Irwin' mangoes for 4 weeks at $12{ }^{\circ} \mathrm{C}$ in an ethylene-scrubbed atmosphere of $5 \mathrm{kPaO}_{2}$ plus $5 \mathrm{kPaCO}_{2}$. Bender et al. (1995) reported that unripe 'Kent' and 'Tommy Atkins' mangoes could be held for $21 \mathrm{~d}$ at $12{ }^{\circ} \mathrm{C}$ in $3 \mathrm{kPa} \mathrm{O}_{2}$ plus $25 \mathrm{kPaCO}_{2}$, and the fruit ripened after $5 \mathrm{~d}$ at $20^{\circ} \mathrm{C}$. Ripening of 'Nam Dok Mai' mangoes was delayed at $20{ }^{\circ} \mathrm{C}$ when $\mathrm{O}_{2}$ was reduced from $19 \mathrm{kPa}$ to 7 $\mathrm{kPa}$ (Yantarasri et al., 1995). 'Manila' and 'Oro' mangoes were not injured, but ripening was delayed, when held in $0.8 \mathrm{kPa} \mathrm{O}_{2}$ and up to $60 \mathrm{kPa} \mathrm{CO}_{2}$ for $160 \mathrm{~min}$ at $48{ }^{\circ} \mathrm{C}$ for insect disinfestation (Yahia et al., 1997). Controlled atmospheres extend shelf life by delaying ripening, but the quality of CA-stored mangoes is only marginally better than that of airstored mangoes (Hatton and Reeder, 1967; Spalding and Reeder, 1974).

Limbanyen et al. (1998) reported that 10 $\mathrm{kPa} \mathrm{O}_{2}$ plus $10 \mathrm{kPa} \mathrm{CO}$ retarded decay and browning of fresh-cut 'Tommy Atkins', 'Haden', and 'Palmer' mangoes. They reported that mangoes should be ripe, have no green color, but not be over-ripe for use as a fresh-cut product. In our preliminary study, we found that 'Tommy Atkins' and 'Kent' mangoes should be between 13 to $27 \mathrm{~N}$ firmness (11.1-mm probe on a Magness-Taylor fruit firmness tester) to have an acceptable quality and reasonable shelf life as a fresh-cut product. The lower limit of acceptable $\mathrm{O}_{2}$ level in packaged fresh-cut mangoes is unknown and needs to be identified for selecting appropriate film for packaging. Additionally, the effects of a combination of low $\mathrm{O}_{2}$ with elevated $\mathrm{CO}_{2}$ on quality changes of fresh-cut mangoes are unknown.

This paper describes the respiration rates and changes in quality and microbial population of fresh-cut 'Kent' and 'Tommy
Atkins' mangoes held in 2 or $4 \mathrm{kPa} \mathrm{O}_{2}$, respectively, plus $10 \mathrm{kPaCO}_{2}$ (balance $\mathrm{N}_{2}$ ) at $5^{\circ} \mathrm{C}$ and $10{ }^{\circ} \mathrm{C}$. The $\mathrm{O}_{2}$ levels were slightly above the breakpoint of the respiratory quotient for the respective cultivars, as determined in preliminary work.

\section{Materials and Methods}

'Tommy Atkins' or 'Kent' mangoes, grown in Mexico, that were heat-treated for insect disinfestation, were purchased at the Maryland Wholesale center in Jessup, Md. They were held at 15 or $20^{\circ} \mathrm{C}$ until most of the fruit had ripened. Selected ripe fruit were placed overnight at $5^{\circ} \mathrm{C}$, and on the following morning, they were washed with $5{ }^{\circ} \mathrm{C}$ water, dipped for $2 \mathrm{~min}$ in $5{ }^{\circ} \mathrm{C} 2.7 \mathrm{~mm}$ sodium hypochlorite solution (adjusted to $\mathrm{pH}$ 7 with citric acid) and allowed to air-dry. Firmness was measured in the middle of one side of the fruit with an $11.1 \mathrm{~mm}$ probe on a Magness-Taylor fruit firmness tester and only fruit having firmness within a 13 to $27 \mathrm{~N}$ range were used for the study.

CA study with 'Tommy Atkins'. Seventyeight 'Tommy Atkins' fruit were separated into three replicates. Fruit were peeled and the flesh was removed from the seed. The flesh was sliced into 2 -cm strips, which were then cut into $2 \times 2$-cm cubes and rinsed in 5 ${ }^{\circ} \mathrm{C} 1.9 \mathrm{~mm}$ sodium hypochlorite solution at $\mathrm{pH} 7$ for $2 \mathrm{~min}$. Each replicate was divided into 16 samples of $\approx 250 \mathrm{~g}$ each and placed on a plastic screen in a 2-L glass jar. Eight lots were placed at 5 and $10^{\circ} \mathrm{C}$ each. The samples for CA treatment were flushed immediately with $\mathrm{N}_{2}$ and $\mathrm{CO}_{2}$ until the gas mixture reached $4 \mathrm{kPa} \mathrm{O}_{2}$ and $10 \mathrm{kPa} \mathrm{CO}_{2}$. Subsequently, air or a gas mixture of $4 \mathrm{kPa} \mathrm{O}_{2}$ plus $10 \mathrm{kPa} \mathrm{CO}_{2}$ (balance $\mathrm{N}_{2}$ ) was metered through the jars at a rate of 10 or $15 \mathrm{~mL} \cdot \mathrm{min}^{-1}$ at 5 or $10^{\circ} \mathrm{C}$, respectively. A jar of each replicate was removed on days $0,3,5$, and 8 for quality and microbial analysis. Respiration rates were measured on samples held for $8 \mathrm{~d}$.

Oxygen uptake and $\mathrm{CO}_{2}$ production were measured every $6 \mathrm{~h}$ with an automatic sampling system (model S-3A/I; Ametek oxygen analyzer; Ametek, Pittsburgh) using a model CP-3A carbon dioxide analyzer (Ametek).

Quality attributes measured were visual quality, shear force, $\mathrm{pH}$, soluble solids, color, and microbial population. Visual quality was scored using a scale of $9=$ excellent, $7=$ good, 5 = fair, 3 = poor, and $1=$ inedible, based on discoloration and watersoaking of the mango cubes. Shear force of a $100 \mathrm{~g}$ sample was determined with a Kramer-Shear cell attached to a Texture Test System (Food Technology Corp., Rockville, Md.) as described elsewhere (Izumi and Watada, 1995). Color of cubes was based on CIE L*, a*, and $b^{*}$ values obtained with the model CR-300 Minolta Chromameter (Minolta Instrument Systems, Ramsey, N.J.), which was calibrated with a white tile. For microbial analysis, a 20$\mathrm{g}$ sample of mango cubes was macerated in

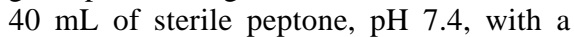
model 400 Lab Stomacher (Seward Medical, London, U.K.). A sample of each homoge- 
nate or appropriate dilution was spread on agar plates using a Whitley Automatic Spiral Plater (Don Whitley Scientific, West Yorkshire, U.K.). Total mesophilic aerobic plate count (APC) was determined by incubating the culture on tryptic soy agar (TSA) (Difco Laboratories, Detroit) at $30^{\circ} \mathrm{C}$ for $24 \mathrm{~h}$. Yeast and molds were determined by incubating cultures on potato dextrose agar (PDA) (Difco) at $30{ }^{\circ} \mathrm{C}$ for $36 \mathrm{~h}$ as described elsewhere (Babic and Watada, 1996).

The study was conducted with three lots of mangoes over a 2-year period.

CA study with 'Kent'. The samples were handled and the quality was analyzed in a similar manner as with 'Tommy Atkins', but the CA treatment was $2 \mathrm{kPa} \mathrm{O}_{2}$ plus $10 \mathrm{kPa}$ $\mathrm{CO}_{2}$. The study was conducted with two lots of mangoes within a 1-year period.

Statistical analysis. PROCGLM of SAS Version 6.12 (SAS Institute, 1989) was used for analysis of variance. Significance of means was determined by Scheffe's test.

\section{Results and Discussion}

CA study with 'Tommy Atkins'. The respiration rate of 'Tommy Atkins' equilibrated to the temperature and atmosphere within $18 \mathrm{~h}$ (data not shown). Immediate flushing of the package to the desired gas level and maintenance of low storage temperature of the cubes probably helped in attaining a steady-state rate rapidly. The average steady-state $\mathrm{CO}_{2}$ production of cubes of all three lots on day 1 at both 5 and $10^{\circ} \mathrm{C}$ was $\approx 6 \mathrm{~mL} \cdot \mathrm{kg}^{-1} \cdot \mathrm{h}^{-1}$. By day 5 , the rate increased sharply to $\approx 10 \mathrm{~mL} \cdot \mathrm{kg}^{-1} \cdot \mathrm{h}^{-1}$, a $66 \%$ increase, with samples held at $10^{\circ} \mathrm{C}$ in air, whereas it increased only slightly to $\approx 7$ $\mathrm{mL} \cdot \mathrm{kg}^{-1} \cdot \mathrm{h}^{-1}$ in $4 \mathrm{kPa} \mathrm{O}$ plus $10 \mathrm{kPa} \mathrm{CO}_{2}$. A similar slight increase $\left(1 \mathrm{~mL} \cdot \mathrm{kg}^{-1} \cdot \mathrm{h}^{-1}\right)$ in rate occurred by day 8 with samples held at $5{ }^{\circ} \mathrm{C}$ in air or $4 \mathrm{kPa} \mathrm{O}_{2}$ plus $10 \mathrm{kPa} \mathrm{CO}$. The CA lowered the respiration rate of fruit at $10{ }^{\circ} \mathrm{C}$, but not at $5{ }^{\circ} \mathrm{C}$.

Quality of cubes deteriorated during holding at a rate influenced by temperature, atmosphere, and lot (Table 1, Fig. 1). The cubes had characteristic mango aroma on day 3 at 5 and $10^{\circ} \mathrm{C}$, but this had diminished by day 5 at $10^{\circ} \mathrm{C}$ and day 8 at $5{ }^{\circ} \mathrm{C}$. The cubes became watery and discolored slightly with time. Severity of watery condition increased with time, whereas discoloration remained minimal. In the preliminary study, very ripe mango cubes discolored more than did ripe cubes, which also was noted by Limbanyen et al. (1998), so very ripe mangoes were not used in this study. Ripe 'Nam Dok Mai' and 'Ok Rong' mangoes grown and marketed in Thailand discolor very rapidly and intensely, so their potential use as fresh-cut product is limited (N. Rattanapanone, personal observation).

Cubes of the three lots behaved slightly differently with respect to atmosphere, as indicated by the significant interaction (Table 1). Quality scores were higher for CA-stored cubes than for those stored in air for lots 2 and 3 (Fig. 1). With cubes of these lots, the deterioration rate of cubes in $\mathrm{CA}$ at $10^{\circ} \mathrm{C}$ was

Table 1. Probability and significance of quality score, yeast population, $\mathrm{L}^{*}$, and hue angle $\left(\mathrm{h}^{\circ}\right)$ of three lots of fresh-cut 'Tommy Atkins' mango cubes stored at 5 or $10^{\circ} \mathrm{C}$, in air or CA for $0,3,5$, or $8 \mathrm{~d}$.

\begin{tabular}{|c|c|c|c|c|c|c|}
\hline Source & $\mathrm{df}$ & Quality score & Yeast/mold & $\mathrm{df}$ & $\mathrm{L}^{*}$ & $h^{\circ}$ \\
\hline Temp (T) & 1 & $0.0001^{* *}$ & $0.0001^{* *}$ & 1 & $0.0014^{* *}$ & $0.0006^{* * *}$ \\
\hline $\operatorname{Atmos}(\mathrm{A})$ & 1 & $0.0001^{* *}$ & $0.0398^{*}$ & 1 & $0.0001^{* *}$ & $0.0021^{* *}$ \\
\hline Day (D) & 3 & $0.0001^{* *}$ & $0.0001^{* * *}$ & 3 & $0.0001^{* * *}$ & $0.0001^{* *}$ \\
\hline Lot (L) & 2 & $0.0001^{* *}$ & 0.1017 & 1 & $0.0001^{* * *}$ & $0.0001^{* * *}$ \\
\hline $\mathrm{T} \times \mathrm{A}$ & 1 & 1.0000 & 0.1094 & 1 & $0.0002^{* *}$ & 0.5432 \\
\hline $\mathrm{T} \times \mathrm{D}$ & 2 & $0.0001^{* *}$ & $0.0001^{* *}$ & 3 & 0.0639 & $0.0057^{* *}$ \\
\hline $\mathrm{T} \times \mathrm{L}$ & 2 & 0.9795 & $0.0177^{*}$ & 1 & $0.0361^{*}$ & 0.3605 \\
\hline$A \times D$ & 3 & $0.0008^{* *}$ & $0.0317^{*}$ & 1 & $0.0001^{* * *}$ & 0.0886 \\
\hline$A \times L$ & 2 & $0.0016^{* *}$ & $0.0242^{*}$ & 1 & 0.4378 & $0.0210^{*}$ \\
\hline $\mathrm{D} \times \mathrm{L}$ & 6 & $0.0017^{* *}$ & $0.0402^{*}$ & 2 & $0.0210^{*}$ & 0.3275 \\
\hline Coef. Var. & & 7.12 & 23.31 & & 3.59 & 1.13 \\
\hline
\end{tabular}

*,** Significant at $P<0.05$ or $<0.01$ by ANOVA and F test.

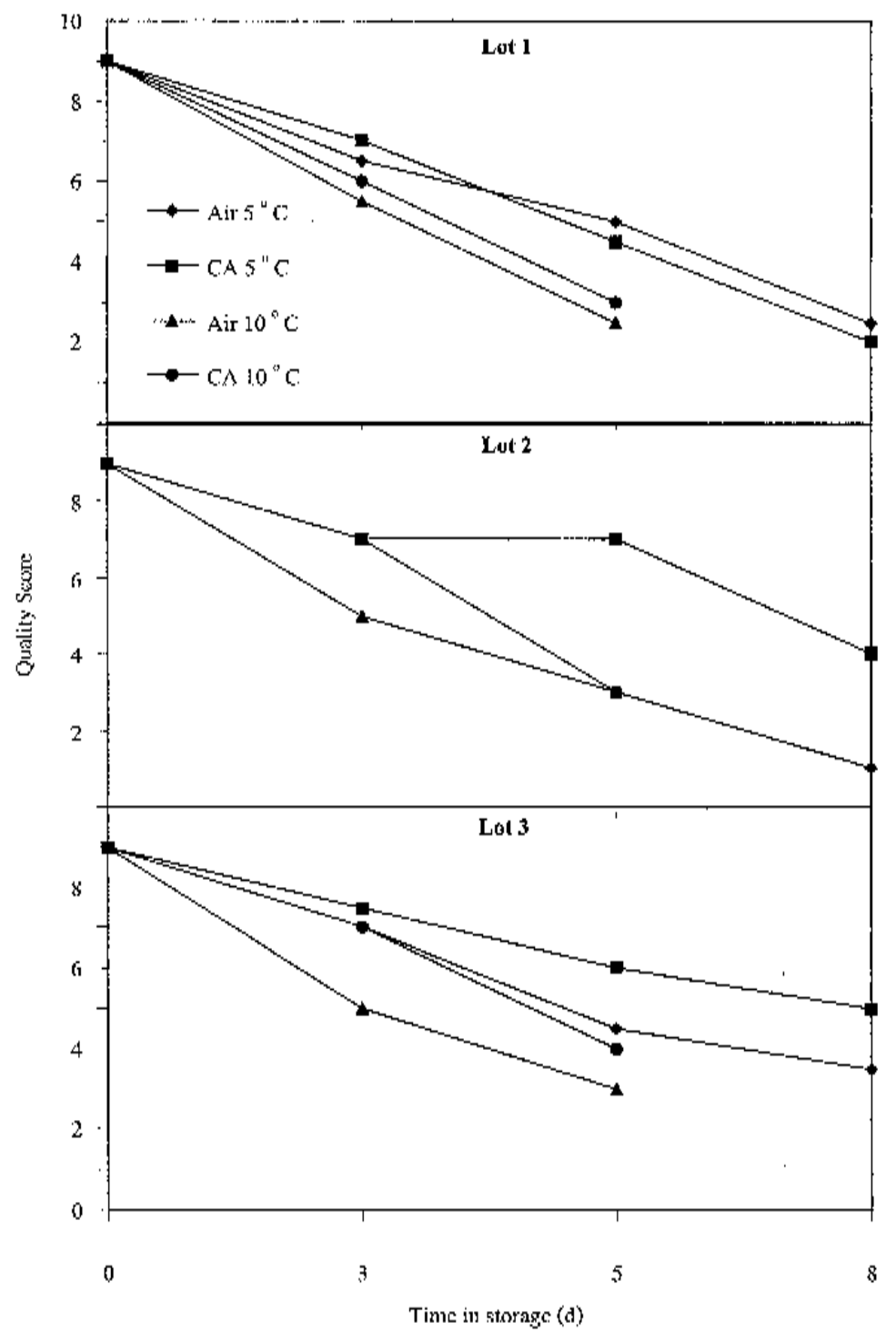

Fig. 1. Average quality ratings $(n=3)$ of three lots of fresh-cut 'Tommy Atkins' mango cubes held in $4 \mathrm{kPa}$ $\mathrm{O}_{2}+10 \mathrm{kPa} \mathrm{CO}_{2} \mathrm{CA}$ or in air at 5 or $10^{\circ} \mathrm{C}$ for $0,3,5$, or $8 \mathrm{~d}$.

similar to that of cubes in air at $5{ }^{\circ} \mathrm{C}$. Controlled atmosphere extended the marketable period of mango cubes by $1 \mathrm{~d}$ (from 3 to $4 \mathrm{~d}$ ) at $10{ }^{\circ} \mathrm{C}$ and by $2 \mathrm{~d}$ (from 4 to $6 \mathrm{~d}$ ) at $5^{\circ} \mathrm{C}$. Cultivar differences are responsible for most of the differences with intact mangoes. Lowering the temperature from 10 to $5^{\circ} \mathrm{C}$ extended the marketable period, which illustrates the importance of low temperatures for handling whole and fresh-cut produce.

Shear force was affected by storage time and differed among samples from individual lots. However, when the data for each lot were analyzed separately, the decreasing shear force with storage time was nonsignificant (data not shown). The firmness of whole fruit at sampling time was similar among the three lots, but the initial shear force was not. Firm- 
ness of mangoes selected for the study ranged from 13 to $27 \mathrm{~N}$, and although the fruit were mixed and selected randomly, the wide range of firmness probably contributed to the large variation in shear force among the replicates. With this large variation, any small effects of temperature, atmosphere or storage time on shear force were not detectable.

The soluble solids content differed among the three lots and was not affected by temperature, atmosphere or storage time (data not shown). The initial average soluble solids content was $11.0 \%$ with samples of lot 2 and $12.7 \%$ and $12.8 \%$ with samples of lots 1 and 3 , respectively. Although initial fruit firmness was similar among the three lots, this was not reflected in the soluble solids content. Since the fruit were initially ripe, and starch to sugar conversion would have been complete, soluble solids content would not be expected to change in the stored cubes.

The $\mathrm{pH}$ of the cubes was affected by atmosphere, storage time, and lots (data not shown), but the range was only $\approx 0.7$ units. The $\mathrm{pH}$ of fresh-cut spinach (Spinacea olevacea L.) increased during storage (Babic and Watada, 1996) while that of fresh-cut honeydew melons (Cucumis melo L., Inodorus Group) (Qi et al., 1999) decreased; thus, the significance of changes of $\mathrm{pH}$ during this short period is unknown.

Color, as determined with the Minolta chromameter, was affected by temperature and atmosphere, changed during storage, and differed among lots (Table 1). The $\mathrm{L}^{*}$ value decreased with time in cubes held in air, but not in those held in CA ( Fig. 2). The change in the $\mathrm{L}^{*}$ value was due to the slight browning on the surface of the cubes and to development of the watery condition. After the initial slight browning on day 3 , browning did not intensify with time. The initial watery condition was noted on day 3 , and continued to increase as indicated by the decreasing $\mathrm{L}^{*}$ value. The hue angle increased with samples in air on day 5 at $10^{\circ} \mathrm{C}$ and on day 8 at $5^{\circ} \mathrm{C}$ (Fig. 2), and occurred when the watery condition increased to the level at which the cubes became unmarketable.

The APC was not affected by any of the treatments (data not shown). In analyzing each lot independently, microbial population on lot 1 was affected by both temperature and atmosphere, and changed with time, whereas in lots 2 and 3 , the population was not affected (data not shown). The initial APC was $\log _{10} 3.78 \mathrm{cfu} / \mathrm{g}$ on cubes of lot 1 and was $\log _{10}$ 4.61 to $5.24 \mathrm{cfu} / \mathrm{g}$ on those of lots 2 and 3 . The population on cubes of lot 1 increased with time and was greater at the higher temperature and in air than in CA, as noted with other fresh-cut products (Babic and Watada, 1996; Qi et al., 1999). However, with cubes of lots 2 and 3, the population remained unchanged. The reason for the lack of typical increase with time in lots 2 and 3 is unknown.

The average population of yeast/mold increased with storage time (Fig. 2). The average population differed with time between samples in CA vs. air and at $10 \mathrm{vs} .5^{\circ} \mathrm{C}$ (Table $1)$. The initial average population was $\log _{10}$
$1.89 \mathrm{cfu} / \mathrm{g}$; this had increased on samples in air to $\log _{10} 5.04 \mathrm{cfu} / \mathrm{g}$ by day 5 at $10^{\circ} \mathrm{C}$ and to $\log _{10} 3.56 \mathrm{cfu} / \mathrm{g}$ by day 8 at $5^{\circ} \mathrm{C}$. The initial and maximum populations were similar to those noted with other fresh-cut products (Babic and Watada, 1996; Qi et al., 1999), and the increase occurred sharply when the visual quality deteriorated.
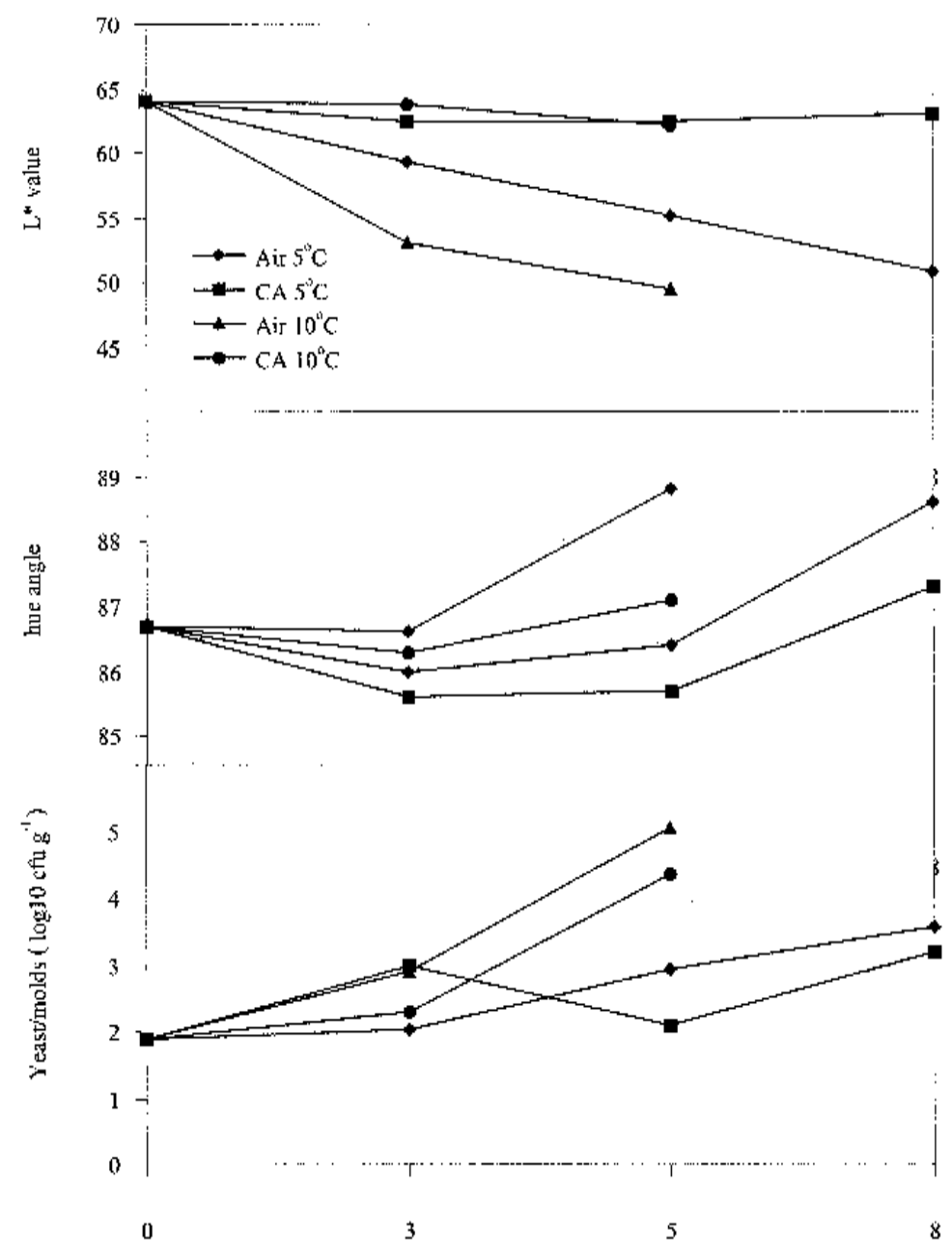

Tine of storage (d)

Fig. 2. Changes of $\mathrm{L}^{*}$ value, hue angle, and yeast population of fresh-cut 'Tommy Atkins' mango cubes held in air or CA at 5 or $10^{\circ} \mathrm{C}$ for $0,3,5$, or $8 \mathrm{~d}$ (average from three lots).

Table 2. Probability and significance of quality score, total mesophilic aerobic plate count (APC), yeast/mold count,and $\mathrm{L}^{*}$ value of three lots of fresh-cut 'Kent' mango cubes held at 5 or $10{ }^{\circ} \mathrm{C}$ in air or $2 \mathrm{kPa} \mathrm{O}_{2}+10 \mathrm{kPa} \mathrm{CO}_{2}$ atmosphere for $0,3,5$, or $8 \mathrm{~d}$.

\begin{tabular}{lcllcc}
\hline \hline Source & df & Quality & APC & Yeast/molds & \multicolumn{1}{c}{ L $^{*}$} \\
\hline Temp (T) & 1 & $0.0001^{* *}$ & $0.0001^{* *}$ & $0.0001^{* *}$ & $0.0001^{* *}$ \\
Atmo (A) & 1 & $0.0001^{* *}$ & $0.0001^{* *}$ & $0.0001^{* *}$ & $0.0001^{* *}$ \\
Day (D) & 3 & $0.0001^{* *}$ & $0.0001^{* *}$ & $0.0001^{* *}$ & $0.0001^{* *}$ \\
Lot (L) & 1 & $0.0001^{* *}$ & $0.0001^{* *}$ & $0.0003^{* *}$ & $0.0001^{* *}$ \\
T $\times$ A & 1 & $0.0288^{*}$ & 0.6018 & 0.7757 & $0.0001^{* *}$ \\
T $\times$ D & 3 & $0.1106^{* *}$ & $0.0001^{* *}$ & $0.0001^{* *}$ & $0.0001^{* *}$ \\
T $\times$ L & 1 & 0.6562 & 0.3070 & 0.2082 & 0.1259 \\
A $\times$ D & 3 & $0.0092^{* *}$ & $0.0012^{*}$ & $0.0001^{* *}$ & $0.0001^{* *}$ \\
A $\times \mathrm{L}$ & 1 & 0.0057 & 0.8800 & 0.7183 & 0.5816 \\
$\mathrm{D} \times \mathrm{L}$ & 3 & $0.0001^{*}$ & $0.0025^{* *}$ & $0.0159^{*}$ & $0.0102^{*}$ \\
$\mathrm{~T} \times \mathrm{A} \times \mathrm{D}$ & 3 & $0.0080^{* *}$ & 0.1822 & $0.0001^{* *}$ & $0.0024^{* *}$ \\
$\mathrm{~T} \times \mathrm{A} \times \mathrm{L}$ & 1 & 0.4588 & 0.9724 & 0.1113 & 0.2275 \\
$\mathrm{~A} \times \mathrm{D} \times \mathrm{L}$ & 3 & 0.6463 & 0.4913 & 0.0511 & 0.0104 \\
$\mathrm{D} \times \mathrm{T} \times \mathrm{L}$ & 3 & $0.0001^{* *}$ & 0.6375 & $0.0443^{*}$ & $0.0025^{* *}$ \\
$\mathrm{~T} \times \mathrm{A} \times \mathrm{D} \times \mathrm{L}$ & 3 & 0.3855 & 0.9645 & $0.0197^{*}$ & 0.5559 \\
\hline
\end{tabular}

*** Significant at $P<0.05$ or $P<0.01$ by ANOVA and F-test.
CA study with 'Kent'. Quality of fresh-cut ' mangoes was affected by temperatwo lots (Table 2) as noted for 'Tommy Atkins'. Watery condition, discoloration, and loss of fresh appearance affected the visual quality. The watery condition was not as rate of quality change differed between the 
severe as that noted on 'Tommy Atkins'. Slight discoloration occurred, particularly on the areas where the skin was removed. Loss of freshness occurred rapidly, as indicated by loss of sheen and aging of tissue.

The cubes from lot 1 remained marketable (score of 5) for $8 \mathrm{~d}$ when held at $5{ }^{\circ} \mathrm{C}$ and for $\approx 2 \mathrm{~d}$ at $10{ }^{\circ} \mathrm{C}$. Darkening of surface tissue with time resulted in reduction of $\mathrm{L}^{*}$ readings (Fig. 3). The average $\mathrm{L}^{*}$ readings differed with temperature, atmosphere, day and lot (Table 2). Although the data were not analyzed for differences between temperatures or atmospheres, the CA atmosphere retarded darkening of tissue, as shown by the higher $\mathrm{L}^{*}$ readings. Loss of sheen was visible with time, did not affect hue angle, which was not affected by any of the treatments, and differed between the two lots (Table 2); average initial values were 85.7 for lot 1 and 84 for lot 2 .

The APC and yeast/mold count increased with deterioration of the tissue (Fig. 3). Although a correlation analysis was not made,
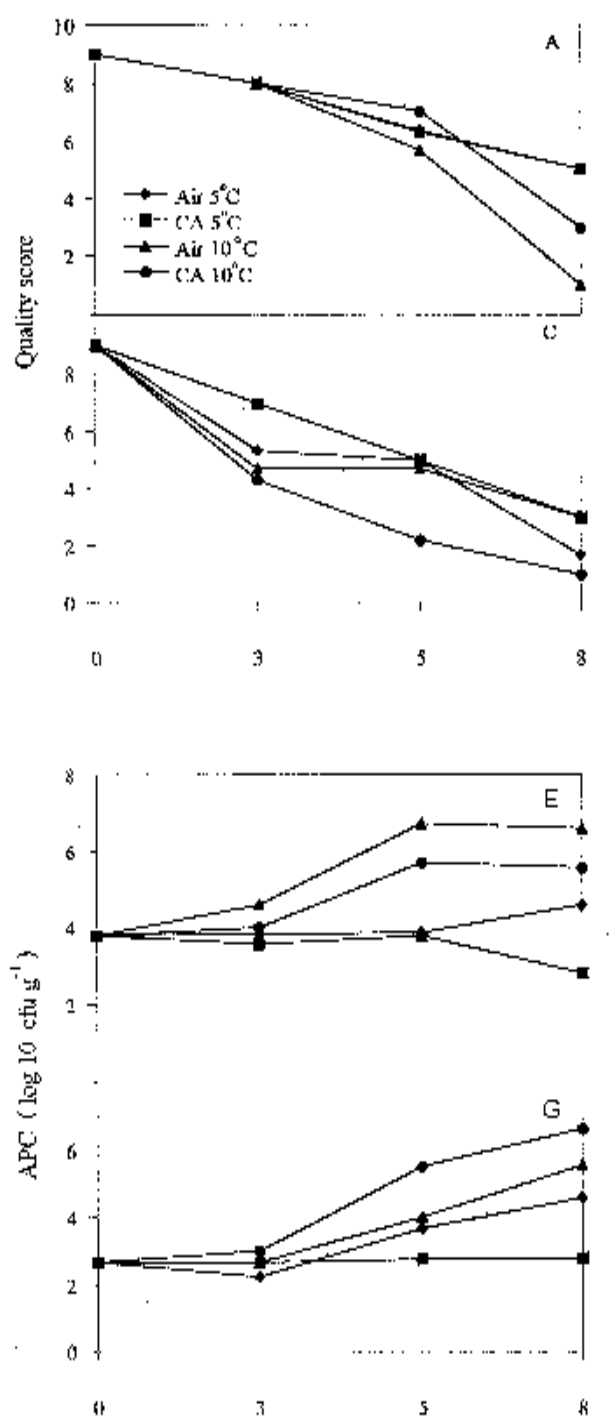

Fig. 3. Quality score, $\mathrm{L}^{*}$ value, and bacteria and yeast population of two lots (A-D and E-H) of fresh-cut 'Kent' mango cubes held at 5 or $10{ }^{\circ} \mathrm{C}$ in $2 \mathrm{kPa} \mathrm{O}_{2}+10 \mathrm{kPa} \mathrm{CO}_{2} \mathrm{CA}$ or air for $0,3,5$, or $8 \mathrm{~d}$.
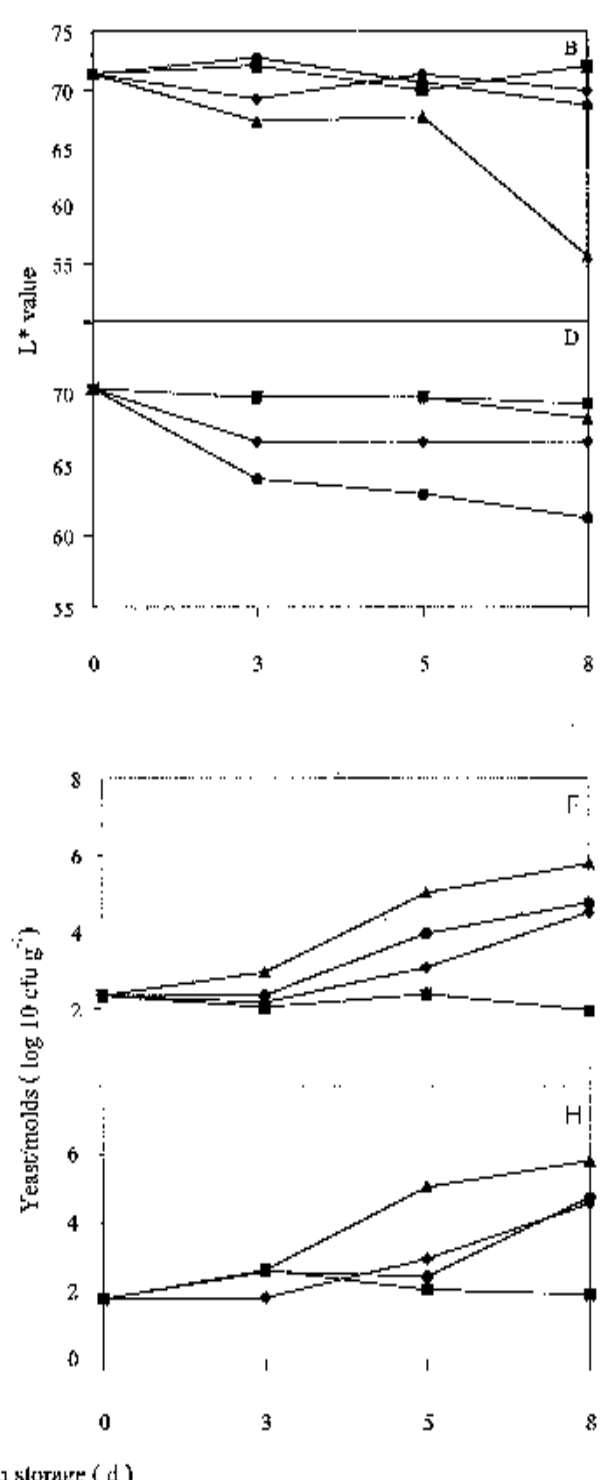

the population was generally greater with cubes having a lower quality score (Fig. 3). The population of APC and yeast/molds differed with temperature, atmosphere, and time (Table 2), generally being greater in air than in $\mathrm{CA}$ and at $10^{\circ} \mathrm{C}$ than at $5{ }^{\circ} \mathrm{C}$ by day 5 and 8 , and increasing with storage time (Fig. 3). The population also differed between the two lots (Table 2); the population increase from day 0 to 8 was greater in lot 1 than in lot 2 (Fig. 3). Interestingly, this difference in the initial count did not affect quality change. The maximum population of bacteria on 'Kent' cubes $\left(\log _{10}\right.$ $6.58 \mathrm{cfu} / \mathrm{g}$ ) was lower, but the maximum population of yeast $\left(\log _{10} 5.80 \mathrm{cfu} / \mathrm{g}\right)$ was similar to that found in other fresh-cut products (Babic and Watada, 1996; Qi et al., 1999).

Shear force, percentage of soluble solids, and $\mathrm{pH}$ of the 'Kent' mango cubes were not affected by temperature or atmosphere, but differed between lots (Table 2). The shear force or change in shear force did not appear to affect the marketability of the cubes. The average initial shear force of lot 1 was $604 \mathrm{~N}$,

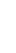 the}

decreasing by $31 \%$ during storage. The average quality score on day 5 was 6.33 . In contrast, the initial shear force of lot 2 was $633 \mathrm{~N}$, decreasing by $17 \%$ during storage, with an average quality score on day 5 of 4.24. The percentage soluble solids did not change during storage, but the initial values of the two lots differed, which probably contributed to the significant differences between lots. The $\mathrm{pH}$ increased only in cubes from lot 1 (data not shown).

'Kent' and 'Tommy Atkins' differed in initial $\mathrm{pH}$ and percentage soluble solids. Initial $\mathrm{pH}$ of 'Kent' ranged from 3.55 to 3.72, while that of 'Tommy Atkins' ranged from 4.0 to 4.6; initial soluble solids of 'Kent' ranged from $15.6 \%$ to $16.8 \%$ and of 'Tommy Atkins' from $11.0 \%$ to $12.8 \%$. These figures would imply that 'Kent' fruit were sweeter and more acidic than 'Tommy Atkins' fruit; thus the effect of these differences on flavor acceptability would be of interest.

One would expect shear force to decrease and percentage soluble solids to increase as fruit ripened, but this did not occur in cubes of either cultivar; the lot with lower shear force did not have a higher soluble solids content, except for lot 2 of 'Tommy Atkins'. With 'Kent', quality of lot 2 deteriorated more rapidly than did that of lot 1 , which may indicate that lot 2 was riper than lot 1 . Consequently, percentage of soluble solids might be a better indicator of ripeness than shear force, but this was not applicable with 'Tommy Atkins'. Perhaps the combination of general skin color and firmness, as used in the trade, is the best indicator of ripeness.

\section{Conclusion}

Marketable period of fresh-cut 'Tommy Atkins' and 'Kent' mango cubes was extended when held in a reduced $\mathrm{O}_{2}$ and elevated $\mathrm{CO}_{2}$ atmosphere, but temperature was the most influential factor. Marketability was limited by development of watery condition, light darkening, and microbial growth on e cubes.

\section{Literature Cited}

Babic, I. and A.E. Watada. 1996. Microbial populations of fresh-cut spinach leaves affected by controlled atmosphere. Postharvest Biol. Technol. 9:187-193.

Bender, R.J., J.K. Brecht, and C.A. Campbell. 1995. Responses of 'Kent' and 'Tommy Atkins' mangoes to reduced $\mathrm{O}_{2}$ and elevated $\mathrm{CO}_{2}$. Proc. Fla. State Hort. Soc. 107:274-277.

Bleinroth, E.W., J.L.M. Garcia, and Y. Yokomizo. 1977. Low temperature, controlled atmosphere conservation of four varieties of mango. Coletanea Inst. Technol. Aliment. (Brazil) $8(1): 217-243$.

Hardenburg, R.E., A.E. Watada, C.Y. Wang. 1986 The commercial storage of fruits, vegetables, and florist and nursery stocks. U.S. Dept. of Agr., Agr. Hdbk. 66.

Hatton, T.T. and W.F. Reeder. 1965. (published 1967). Controlled atmosphere storage of Keitt mangoes. Proc. Carib. Reg. Amer. Soc. Hort. Sci. 19:114-119.

Izumi, H. and A.E. Watada. 1995. Calcium treat- 
ments to maintain quality of zucchini squash slices. J. Food Sci. 60:789-793.

Kapur, N.S., K.S. Rao, and H.S. Srivastava. 1962. Refrigerated and gas storage of mangoes. Food Sci. 11(8):228-231.

Limbanyen, A., J.K. Brecht, S.A. Sargent, and J.A. Bartz. 1998. Fresh-cut mango fruit slices. HortScience 33:457. (Abstr.)

Maekawa, T. 1990. On the mango CA storage and transportation from subtropical to temperate regions in Japan. Acta Hort. 269:367-374.
Qi, L., T. Wu, and A.E. Watada. 1999. Quality changes of fresh-cut honeydew melons during controlled atmosphere storage. J. Food Qual. 22:513-521.

SAS Institute, Inc. 1989. SAS/Stat user's guide vers. 6, 4th ed., SAS Inst., Cary, N.C.

Spalding, D.H. and W.F. Reeder. 1974. Current status of controlled atmosphere storage of four tropical fruits. Proc. Fla. State Hort. Soc. 87:334-337.

Yahia, E.M., D. Ortega, P. Santiago, and L.
Lagunez. 1997. Responses of mango and mortality of Anastrepha ludens and A. obliqua to modified atmospheres at high temperatures. CA'97 Proc. Vol. 1, CA technology and disinfestation studies. Univ. of Calif. Postharvest Hort. Ser. No. 15:105-112.

Yantarasri, T., S. Ben-Yehoshua, V. Rodov, W. Kumpuan, J. Utahibutra, and J. Sornsrivichai. 1995. Development of perforated modified atmosphere package for mango. Acta Hort. 398:81-91. 